\title{
LOCAL INJECTION OF HYDROCORTISONE AND PROCAINE IN OSTEO-ARTHRITIS OF THE HIP JOINT
}

\author{
BY \\ V. M. LEVEAUX AND C. E. QUIN \\ Arthur Stanley Institute, Middlesex Hospital, London
}

(RECEIVED FOR PUBLICATION JULY 30, 1956)

The local injection of therapeutic substances to relieve symptoms in osteo-arthritis has long been a controversial method of treatment. Desmarais (1952) reviewed the use of various substances, including procaine lactic acid, acid potassium phosphate, and procaine. He further critically examined the results of his own series of 189 injections into hip or knee joint with alkaline procaine, lactic acid, saline, or needle prick alone. There appeared to be little difference between the results with these various materials, except that procaine gave slightly more pain relief and was probably the substance of choice.

The introduction of hydrocortisone (Compound F) stimulated further studies in relation to osteoarthritis of the hip joint. Hollander, Brown, Jessar, and Brown (1951) reported the responses of two patients suffering from unilateral osteo-arthritis of the hip to the injection of $25 \mathrm{mg}$. hydrocortisone into the region of the affected joint. They stated that "a prompt alleviation of symptoms and improvement in range of motion was noted in both patients after 24 hours; this persisted for 7 days in one and 13 days in the other". Two years later Hollander (1953) was able to report on 77 injections into osteoarthritic hips, in which relief was obtained for at least 3 days in 47 per cent. of cases.

\section{Approach to the Hip Joint}

The majority of workers have approached the joint anteriorly, a method which Dobson (1950) found to be successful in 67 per cent. of a cadaver series.

Landsmeer and Koumans (1954) described an approach from the caudo-lateral aspect. In this method the needle is inserted at a point up to $5 \mathrm{~cm}$. caudal to the base of the greater trochanter and is directed upwards towards a point on the middle third of a line between the anterior-superior iliac spine and the pubic tubercle. By this means the needle passes over the anterior aspect of the femoral neck to be arrested by the caudal aspect of the femoral head. At this point the needle should be within the joint space.

Clearly the injection of a deeply-placed joint like the hip joint can never be as straightforward a procedure as that of an accessible joint such as the knee. Nevertheless, this method of injection was found to be generally satisfactory in the present series, and less of an ordeal for the patient than the anterior approach since the sensitive groin area was avoided. A 4-in. 20 B.W.G. needle was adequate for most cases, but in a few large or obese subjects a 6-in. 18 B.W.G. needle was used.

Fig. 1 (opposite) shows the patient with skin markings delineated, including the anterior part of the iliac crest and the greater trochanter. The two vertical lines in the groin represent the limits of the middle third of the line between the anterior-superior iliac spine and the pubic tubercle. The needle is passing through anaesthetized skin and shows the general direction of aim. Fig. 2 (opposite) shows an $x$-ray film of an injection into the opposite hip of the patient shown in Fig. 1.

Fig. 3 (overleaf) shows the relationship of the surface markings rendered visible by overlying copper wire to the hip joint and injecting needle. Fig. 4 (overleaf) illustrates a practical snag, the needle point being arrested by the inter-trochanteric line.

This caudo-lateral approach was used throughout the present series.

\section{Present Investigation}

The object of the investigation was to compare the effect of an injection of $5 \mathrm{ml}$. 2 per cent. procaine (Injection " $P$ ") with that of a combined injection of $50 \mathrm{mg}$. hydrocortisone and $5 \mathrm{ml} .2$ per cent. procaine (Injection " $\mathrm{H}$ "). 


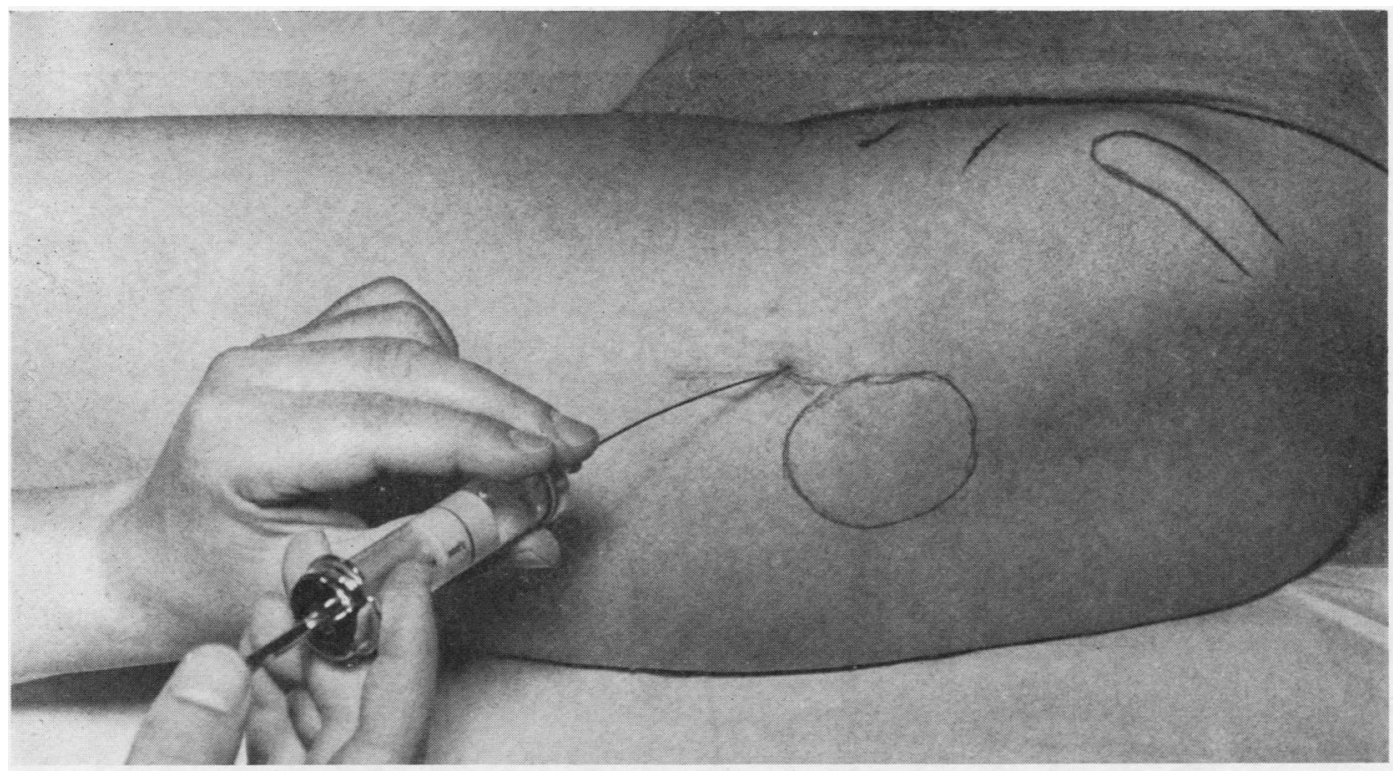

Fig. 1.-Surface markings delineated and insertion of needle.

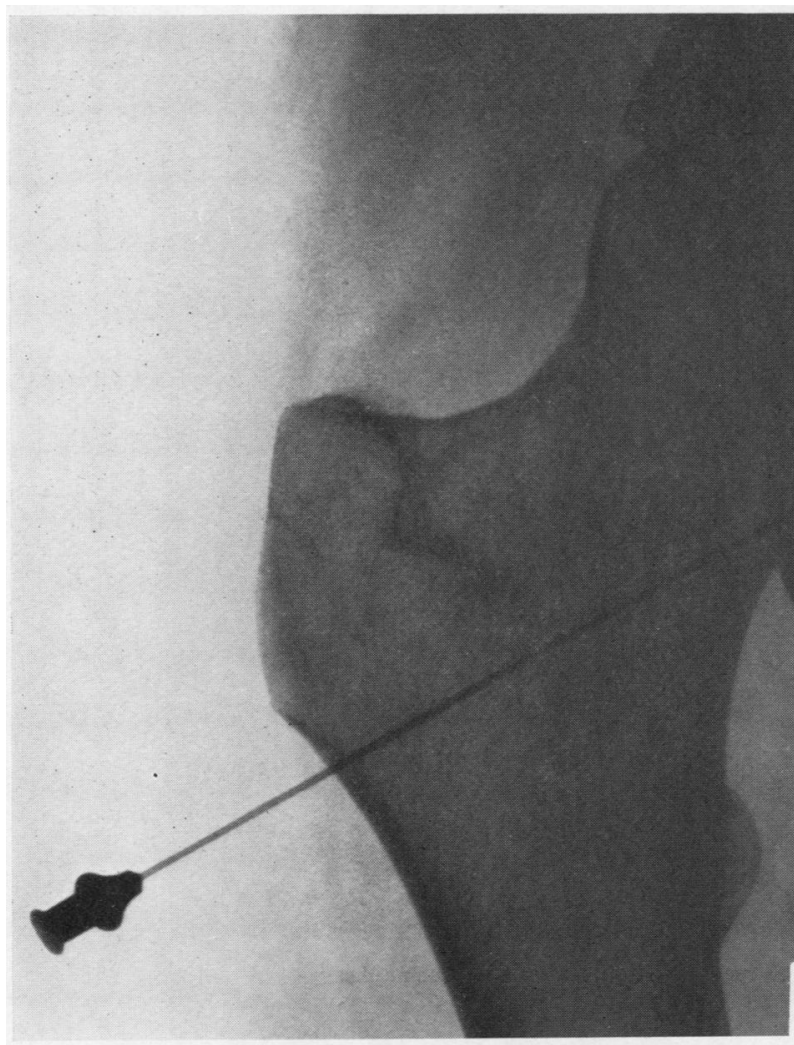

Fig. 2.-Insertion of needle completed. 


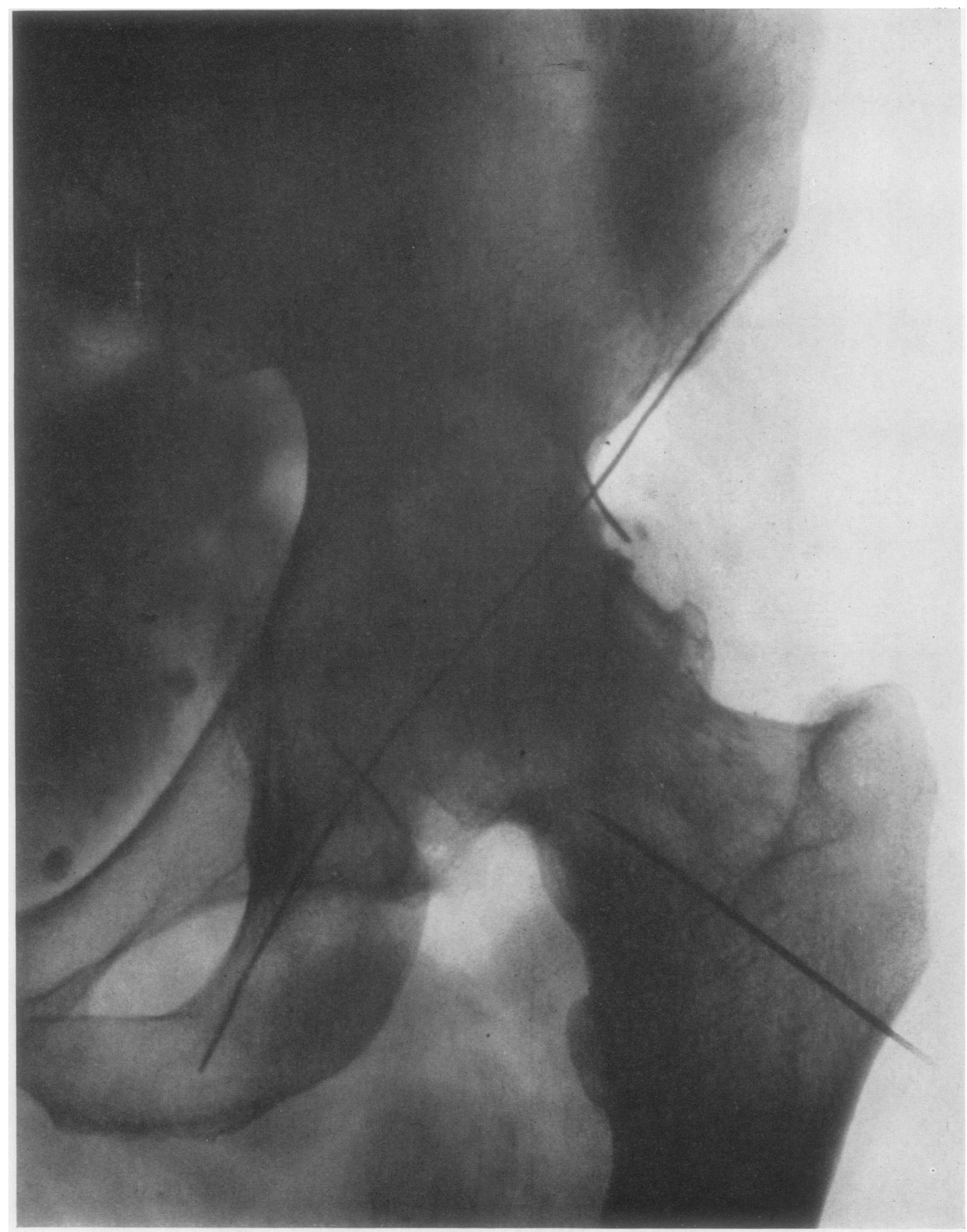

Fig. 3.-Relationship of the surface markings to hip joint and needle. 


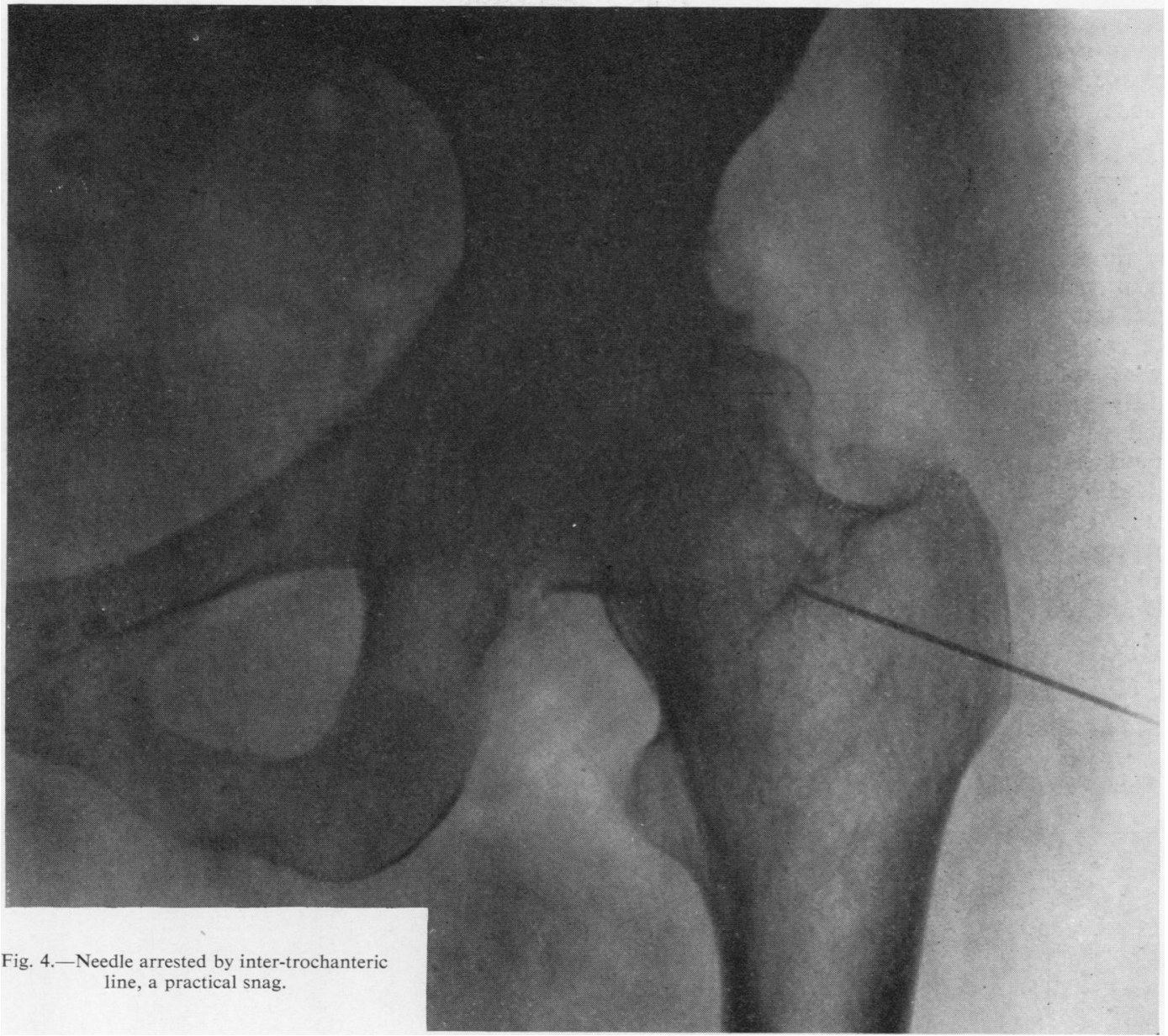

Thirty patients were divided into two groups of fifteen. In Group I, Injection "P" was given first, and later, when any benefit obtained had worn off, Injection " $H$ " was given. In Group II the order of injection was reversed. The patients were not informed of any difference between the two injections.

Each patient was assessed immediately before the injection and again one week after. Thereafter observation was maintained until it was evident that any benefit obtained had worn off.

The chief measure of benefit was that of pain relief. In addition the distance between the medial malleoli on full abduction of the legs was made and the time taken to walk ten times the length of a 35-foot corridor were recorded. Both these measurements were taken immediately before and one week after the injection.
Radiological Classification of Severity of Disease. -The cases were allotted to the following broad groups:

0. No radiological change (four joints showed no radiological change but on clinical grounds were considered to be osteo-arthritic).

1. Slight loss of cartilage space. Early new bone formation.

2. Moderate loss of cartilage space. Moderate new bone formation. Subchondral sclerosis. Lipping. Early cyst formation. Periosteal new bone along neck of femur.

3. Severe or complete loss of cartilage space. Deformity of femoral head. Marked cyst formation. Gross new bone formation.

A simple addition of the Group numerals in each joint injected gives an empirical measure of the severity of involvement in Groups I and II. In 
some patients with clinical bilateral disease, the second injection was sometimes given into the opposite joint from the first, so a separate addition is made for Injections " $\mathrm{P}$ " and " $\mathrm{H}$ " in each Group.

\section{Summary of Results}

The results are set out in detail in Tables I and II. The results of the first injection show a marked similarity in the effect of Injections " $P$ " and " $H$ ". Relief was obtained in eleven of the fifteen cases in each group after the first injection. Injection " $P$ ", however, produced a longer average period of relief, namely 3.07 weeks per patient (Table I) as compared with 1.6 weeks (Table II). Injection "P" diminished the average time over the standard course by $18.3 \mathrm{sec}$. (Table I) and Injection "H" by $10.8 \mathrm{sec}$. (Table II). On radiological assessment the groups were comparable, having an empirical total of 31 for Injection " $P$ " in Group I and 33 for Injection " $\mathrm{H}$ " in Group II. Therefore, on the evidence of the first injection alone, Injection "P" would seem to be superior to Injection " $\mathrm{H}$ " in duration of benefit and increase in mobility.

The results of the second injection were in marked contrast to those of the first. Injection "P" relieved only one case, whereas Injection " $\mathrm{H}$ " relieved thirteen cases. Ten cases were made worse by Injection "P" as compared with one by Injection "H". The average duration of benefit was 0.057 weeks with Injection "P" and $2 \cdot 5$ weeks with Injection " $H$ ". In the Injection "P" patients, the time over the standard course was actually increased by an average of $12 \cdot 3$ seconds, whereas with Injection " $\mathrm{H}$ ", it was reduced by an average of $7 \cdot 3$ seconds. The radiological assessment of the severity of disease gave an empirical total of 34 with Injection " $H$ " in Group I and 33 with Injection " $P$ " in Group II.

As regards objective measurement of hip movement represented by the intermalleolar distance on full abduction in this series no definite change was

TABIE. I

GROUP

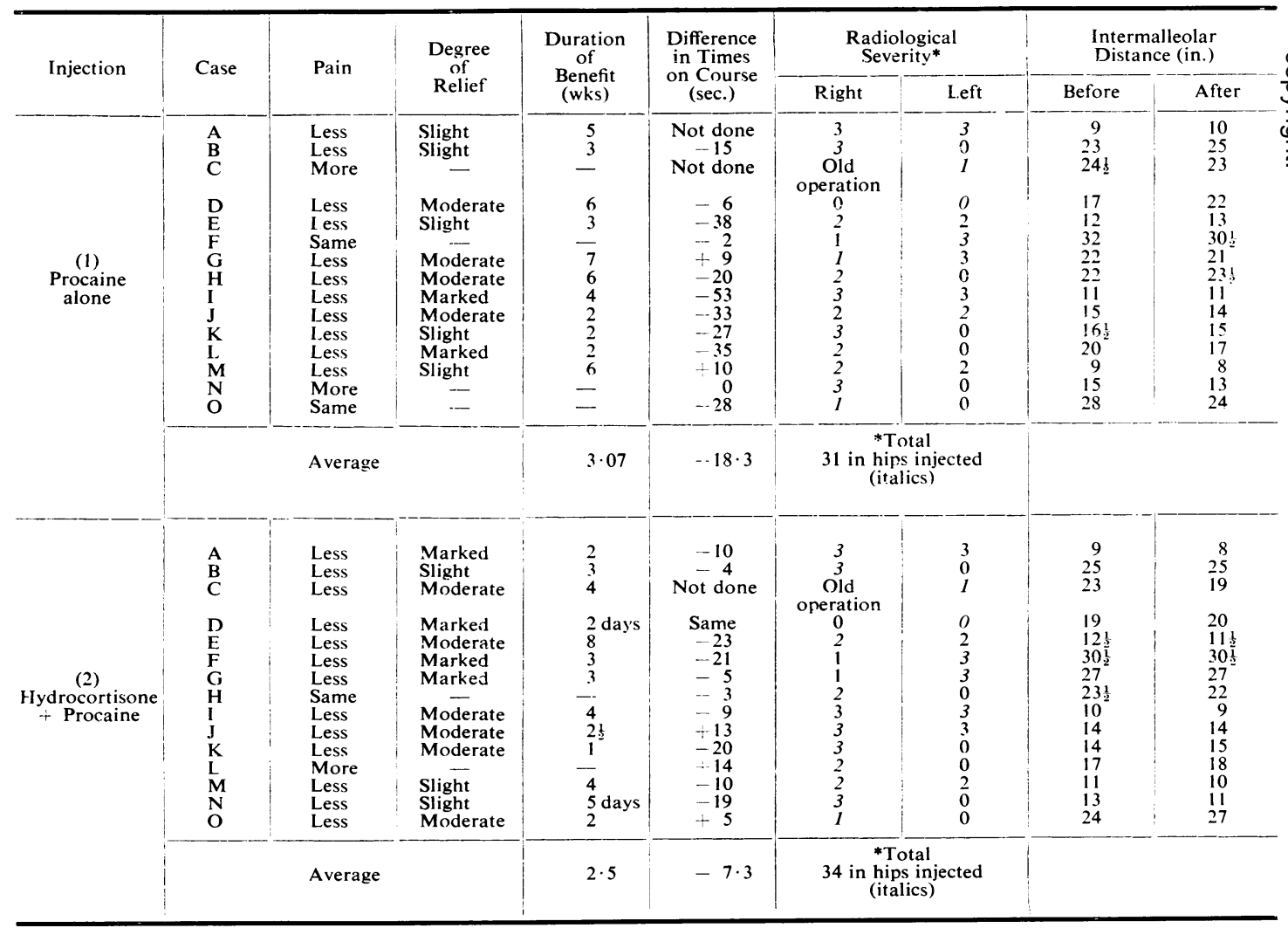


TABLE II

GROUP II

\begin{tabular}{|c|c|c|c|c|c|c|c|c|c|}
\hline \multirow[t]{2}{*}{ Injection } & \multirow[t]{2}{*}{ Case } & \multirow[t]{2}{*}{ Pain } & \multirow{2}{*}{$\begin{array}{l}\text { Degree } \\
\text { of } \\
\text { Relief }\end{array}$} & \multirow{2}{*}{$\begin{array}{c}\text { Duration } \\
\text { of } \\
\text { Benefit } \\
\text { (wks) }\end{array}$} & \multirow{2}{*}{$\begin{array}{l}\text { Difference } \\
\text { in Times } \\
\text { on Course } \\
\text { (sec.) }\end{array}$} & \multicolumn{2}{|c|}{$\begin{array}{c}\text { Radiological } \\
\text { Severity* }\end{array}$} & \multicolumn{2}{|c|}{$\begin{array}{l}\text { Intermalleolar } \\
\text { Distance (in.) }\end{array}$} \\
\hline & & & & & & Right & Left & Before & After \\
\hline \multirow[t]{2}{*}{$\begin{array}{l}\text { (1) } \\
\text { Hydrocortisone } \\
+ \text { Procaine }\end{array}$} & $\begin{array}{l}\mathbf{P} \\
\mathbf{Q} \\
\mathbf{R} \\
\mathbf{S} \\
\mathbf{T} \\
\mathbf{U} \\
\mathbf{V} \\
\mathbf{W} \\
\mathbf{X} \\
\mathbf{Y} \\
\mathbf{Z} \\
\mathbf{A} 2 \\
\mathbf{B} 2 \\
\mathbf{C} 2 \\
\mathbf{D} 2\end{array}$ & $\begin{array}{l}\text { Less } \\
\text { Less } \\
\text { More } \\
\text { Less } \\
\text { Less } \\
\text { Same } \\
\text { Less } \\
\text { Less } \\
\text { Same } \\
\text { Less } \\
\text { Less } \\
\text { Same } \\
\text { Less } \\
\text { Less } \\
\text { Less }\end{array}$ & $\begin{array}{l}\text { Moderate } \\
\text { Marked } \\
\text { Moderate } \\
\text { Slight } \\
\text { Slight } \\
\text { Moderate } \\
\text { Slight } \\
\text { Marked } \\
\text { Moderate } \\
\text { Moderate } \\
\text { Slight }\end{array}$ & $\begin{array}{l}2 \\
\frac{2}{3} \\
\frac{1}{2} \\
\frac{2}{1} \\
\frac{1}{2} \\
4 \\
\frac{1}{4} \\
4\end{array}$ & $\begin{array}{l}-21 \\
-\quad 3 \\
-1 \\
+27 \\
+7 \\
+6 \\
-23 \\
-1 \\
-8 \\
-61 \\
-34 \\
+13 \\
-1 \\
+6 \\
-68\end{array}$ & $\begin{array}{l}3 \\
0 \\
3 \\
3 \\
3 \\
1 \\
3 \\
0 \\
0 \\
3 \\
2 \\
0 \\
1 \\
3 \\
2\end{array}$ & $\begin{array}{l}0 \\
3 \\
0 \\
2 \\
3 \\
0 \\
2 \\
2 \\
1 \\
2 \\
3 \\
1 \\
0 \\
2 \\
3\end{array}$ & $\begin{array}{l}19 \frac{1}{2} \\
24 \\
32 \\
11 \\
14 \\
38 \\
4 \\
25 \frac{1}{2} \\
27 \\
13 \\
16 \frac{1}{2} \\
36 \\
29 \\
25 \frac{1}{2} \\
12 \frac{1}{2}\end{array}$ & $\begin{array}{l}191 \\
23 \frac{1}{2} \\
32 \frac{1}{2} \\
10 \\
13 \frac{1}{2} \\
41 \frac{1}{2} \\
6 \\
26 \\
27 \\
12 \frac{1}{2} \\
16 \frac{1}{2} \\
35 \frac{1}{2} \\
27 \frac{1}{2} \\
25 \\
13 \frac{1}{2}\end{array}$ \\
\hline & \multicolumn{3}{|c|}{ Average } & $1 \cdot 6$ & $-10 \cdot 8$ & \multicolumn{2}{|c|}{ 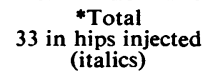 } & & \\
\hline \multirow[t]{2}{*}{$\begin{array}{l}(2) \\
\text { Procaine } \\
\text { alone }\end{array}$} & $\begin{array}{l}\mathbf{P} \\
\mathbf{Q} \\
\mathbf{R} \\
\mathbf{S} \\
\mathbf{T} \\
\mathbf{U} \\
\mathbf{V} \\
\mathbf{W} \\
\mathbf{X} \\
\mathbf{Y} \\
\mathbf{Z} \\
\mathbf{A} 2 \\
\mathbf{B} 2 \\
\mathbf{C} 2 \\
\mathbf{D} 2\end{array}$ & $\begin{array}{l}\text { More } \\
\text { More } \\
\text { More } \\
\text { More } \\
\text { Same } \\
\text { Same } \\
\text { More } \\
\text { More } \\
\text { More } \\
\text { More } \\
\text { More } \\
\text { Same } \\
\text { More } \\
\text { Same } \\
\text { Less }\end{array}$ & $\begin{array}{c}= \\
= \\
= \\
= \\
= \\
= \\
= \\
\overline{-} \\
\text { Moderate }\end{array}$ & $\begin{array}{l}= \\
= \\
= \\
= \\
= \\
= \\
= \\
= \\
\overline{-} \\
6 \text { days }\end{array}$ & $\begin{array}{r}+34 \\
\text { Same } \\
+10 \\
-5 \\
+20 \\
+1 \\
-17 \\
-12 \\
-4 \\
+76 \\
+45 \\
-3 \\
-1 \\
+26 \\
+15\end{array}$ & $\begin{array}{l}3 \\
0 \\
3 \\
3 \\
3 \\
1 \\
3 \\
0 \\
0 \\
3 \\
2 \\
0 \\
1 \\
3 \\
2\end{array}$ & $\begin{array}{l}0 \\
3 \\
0 \\
2 \\
3 \\
0 \\
2 \\
2 \\
1 \\
2 \\
3 \\
1 \\
0 \\
2 \\
3\end{array}$ & $\begin{array}{l}19 \\
22 \frac{1}{2} \\
32 \\
8 \frac{1}{2} \\
14 \\
41 \frac{1}{2} \\
5 \\
22 \frac{1}{2} \\
27 \\
13 \\
16 \frac{1}{2} \\
37 \\
27 \frac{1}{2} \\
26 \\
13\end{array}$ & $\begin{array}{c}19 \frac{1}{2} \\
21 \frac{1}{2} \\
32 \\
9 \frac{1}{2} \\
13 \frac{1}{2} \\
41 \\
6 \\
24 \\
261 \\
11 \\
14 \frac{1}{2} \\
35 \\
32 \\
24 \\
12\end{array}$ \\
\hline & & \multicolumn{2}{|c|}{ Average } & 0.057 & $+12 \cdot 3$ & \multicolumn{2}{|c|}{ 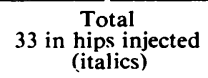 } & & \\
\hline
\end{tabular}

TABLE III

SUMMARY OF RESULTS IN GROUPS I AND II

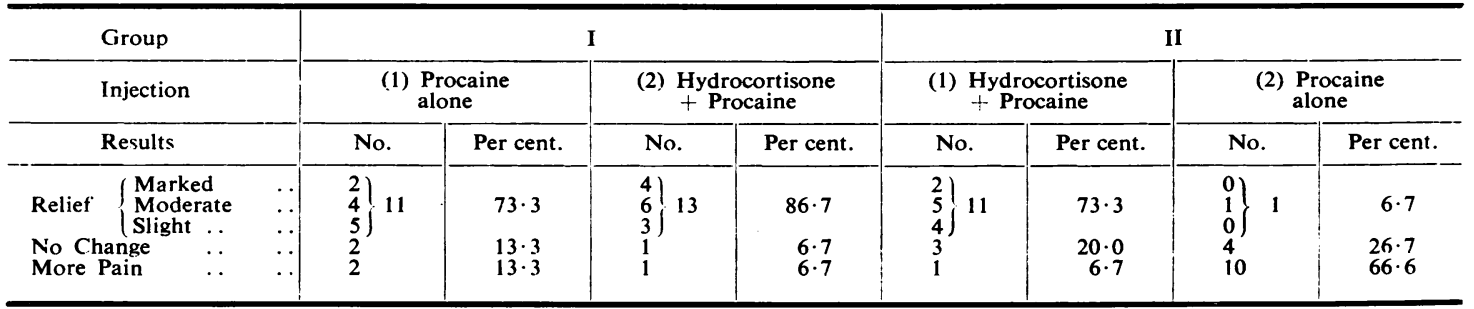

noted. This figure, however, gives a clinical guide to the severity of the mechanical disability produced by the disease.

\section{Discussion}

It is difficult to explain this marked difference between the first and second injections on a purely organic basis. The technique used was apparently the same in each case, any inadequacy in method being applicable to each group equally.

The psychological response to a new and rather dramatic form of treatment cannot be overlooked, and makes evaluation of a first injection with any therapeutic substance difficult. Probably second and subsequent injections are necessary before the real worth of the procedure can be appreciated.

Our observations on patients in this series, and our experience in other cases, leads us to believe that procaine alone is far inferior to the combined hydrocortisone and procaine injection, and frequently causes an increase in pain. The combined 
injection, on the other hand, does appear to be of definite value as a palliative measure in the treatment of osteo-arthritis of the hip. The patients have usually had many forms of treatment without much benefit, and to them the relief of pain following the combined injection has been most welcome. Not least of all a few comfortable nights in bed, with changes of position proving relatively painless, are encouraging. This relief of symptoms can often be obtained again by a further injection when it becomes necessary.

The method of injection used in this series is not difficult, nor is it a great ordeal for the average patient. In sensitive patients with a dread of the needle, however, this treatment is probably better avoided. The results obtained compare favourably in our experience with the usual methods of physical treatment employed for osteo-arthritis of the hip.

It must be emphasized, however, that this form of treatment is only a palliative measure, and that there are no grounds for believing that repeated injections will in any way alter the course of the disease. Nevertheless, injection of hydrocortisone with procaine may be of great value in helping a patient over a particularly painful episode. Surgical procedures in selected cases offer the best chance of obtaining a lasting relief of pain in osteo-arthritis of the hip. In our opinion injections of hydrocortisone with procaine have a part to play in the management of those patients in whom operation is not considered advisable, or who have to face a waiting period before operation.

\section{Summary}

Using the caudo-lateral approach in cases of osteo-arthritis of the hip joint, a comparison was made between an injection of $5 \mathrm{ml}$. 2 per cent. procaine and a combined injection of $50 \mathrm{mg}$. hydrocortisone and $5 \mathrm{ml}$. 2 per cent. procaine. Fifteen patients received the procaine alone first, and the combined injection subsequently, when all benefit of the first had worn off. Fifteen patients received the injections in the reverse order.

The results of the first injection in each group were remarkably similar as regards relief of pain and increase of mobility. The results of the second injection were very different and showed procaine alone to be markedly inferior to the combined hydrocortisone and procaine injection.

The influence of psychological factors on the response to first injections is emphasized, and the value and limitations of the combined injection are discussed.

It is concluded that procaine and hydrocortisone combined are of value as palliative substances used by local injection into the region of a painful osteoarthritic hip joint.

We wish to acknowledge the helpful advice and encouragement given to us by Dr. Oswald Savage and Dr. A. C. Boyle throughout this work, and to thank Miss A. E. Bartholomew and Miss Y. V. Townshend for their assistance. We should also like to thank Dr. I. Yentis for help in the radiological grading of the cases.

\section{REFERENCES}

Desmarais, M. H. L. (1952). Annals of the Rheumatic Diseases

11, 277. ' (1950). Ibid., 9, 237.

Hollander, J. L. (1953). J. Bone Jt Surg., 35A, 983.

, Brown, E. M., Jessar, R. A., and Brown, C. Y. (1951). J. Ame med. Ass., 147, 1629.

Landsmeer, J. M. F., and Koumans, A. K. J. (1954). Annals of the Rheumatic Diseases, 13, 246.

Injections locales d'hydrocortisone et de procaine dans l'ostéo-arthrite de la hanche

\section{RÉSUMÉ}

En utilisant une approche caudo-latérale dans des cas d'ostéo-arthrite de la hanche, on compara l'injection de $5 \mathrm{cc}$. de procaïne à $2 \%$ et l'injection combinée de $50 \mathrm{mg}$. d'hydrocortisone et de $5 \mathrm{cc}$. de procaïne à $2 \%$. Quinze malades reçurent d'abord la procaïne seule, puis l'injection combinée, après que tout bénéfice dû à la première eut disparu. Quinze malades reçurent les injections dans l'ordre inverse.

Les résultats de la première injection, dans chaquધ groupe, furent remarquablement semblables en ce qu concerne le soulagment de la douleur et l'augmentation de la mobilité. Les résultats de la seconde injectioñ furent très différents et montrèrent que la procaïne seule était nettement inférieure à la combinaison procaïnehydrocortisone.

L'influence des facteurs psychologiques sur la réponse aux premières injections est soulignée, et la valeur et les limites des injections combinées sont discutées.

On conclue que la procaine et l'hydrocortisone sont utiles comme substances palliatives en injection locale dans la région d'une hanche ostéo-arthritique douloureuse.

\section{Inyecciones locales de hidrocortisona y de procaina en la osteo-artritis de la cadera}

\section{SUMARIO}

Empleando el acceso caudo-lateral en casos de osteoartritis de la cadera, se compararon las inyecciones de $\frac{\mathrm{O}}{\supset}$ $5 \mathrm{cc}$. de procaina a $2 \%$ con las inyecciones combinadas de $50 \mathrm{mg}$. de hidrocortisona y de $5 \mathrm{cc}$. de procaina a $2 \%$. 을. Quince enfermos recibieron al principio la procaina sola y luego, al desaparecer enteramente el beneficio de la N primera inyección, la inyección combinada. Otros quince enfermos recibieron las inyecciones en el orden inverso.

Los resultados de la primera inyección fueron, en ambos grupos, señaladamente parecidos respecto al alivio del dolor y el aumento de la movilidad. Los 6 resultados de la segunda inyección fueron muy diferentes y mostraron que la procaina sola fué netamente inferior $\stackrel{\mathscr{C}}{?}$ a la procaina-hidrocortisona combinadas. 
Se subraya la influencia de los factores sicológicos sobre la respuesta a las primeras inyecciones y se discuten el valor y los límites de las inyecciones combinadas.
Se concluye que la procaina y la hidrocortisona son paliativos útiles en inyecciones locales en la región de la cadera osteo-artrítica dolorosa. 